\title{
An Explanatory Model for Individual Performance Based on a Commitment Human Resource Approach
}

Valiollah Mirzaei Alamooti ${ }^{1}$ Ph.D. Human Resources Management, Department of Public Administration, Qazvin Branch, Islamic Azad University, Qazvin, Iran (Author Corresponding).

Mohammad Ataei ${ }^{2}$ Assistant Professor, Department of Public Administration, Qazvin Branch, Islamic Azad University, Qazvin Iran.

Zoreh Moghadas ${ }^{3}$ Assistant Professor, Department of Math, Qazvin Branch, Islamic Azad University, Qazvin, Iran.

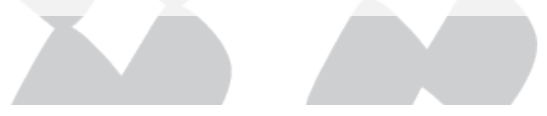

\begin{abstract}
Enhancing employee performance is of great concern among state organizations. The purpose of this article is to study the impact of perceived committed HRM on individual performance with the mediating roles of job stress and job commitment and the moderating roles of job skills and perceived supervisor support among the employees of the Education Department of Qazvin Province. Based on Morgan's Table, 260 subjects comprised the statistical sample. It was a survey study and questionnaires were applied to gather data. Data analysis was performed through structural equation modeling based on variance analysis. Findings indicate that there is direct relation between committed HRM and employee performance; the mediating role of job commitment between perceived committed HRM and employee performance is positive and significant, but work stress plays no mediating role between these latter variables. Moreover, regarding the amount of the statistic " $t$ ", the moderating role of perceived supervisor support between perceived committed HRM and work stress is positive and significant; however, job skills play no moderating role between perceived committed HRM and job commitment.
\end{abstract}

Keywords: Perceived Committed HRM, Work Stress, Job Commitment, Job Skills, Perceived Supervisor Support.

1. Mirzaei.vali@qiau.ac.ir

2.ataei@qiau.ac.ir

3.Zmoghaddas@qiau.ac.ir 


\section{مقدمه}

مديريت منابع انسانى اثربخش براى موفقيت هر سازمانى حياتى است. كيفيت منابع انسانى

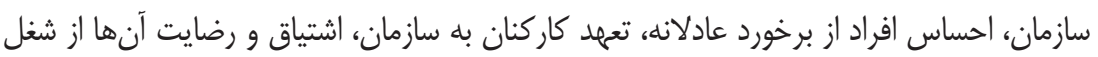
و تجربياتشان، همخى بر بهرهورى سازمان، خدمات مشترى، شهرت سازمان، و بقاى آن اثرگذار

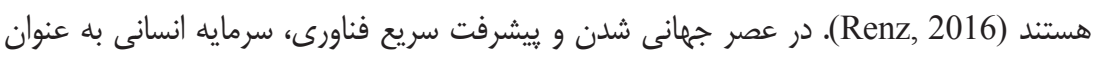
مهمثرين سرمايه سازمانها قلمداد مىشود. سرمايه انسانى مجموعهاى از مهارتها، دانش، و ويزَّى هاى عمومى افراد در سازمان است و مىتواند نشاندهنده ظرفيت انجام كار امروز و فردا باشد

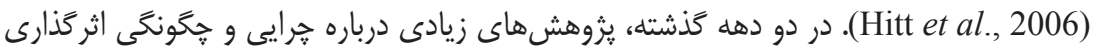
اقدامهاى مديريت منابع انسانى بر كسب مزيت رقابتى انجام شده است. اگرجه، يزوهشهايى كه با

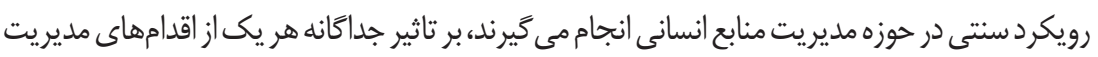
منابع انسانى تمر كز دارند، اما يزوهش هايى كه در حوزه مديريت منابع انسانى رويكرد راهبردى دارند، بر

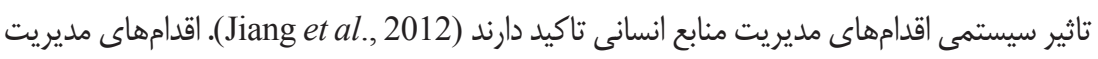
منابع انسانى منعكس كننده نحوه نخرش سازمان درباره كاركنان است. كاركنان بر اساس قضاوت شخصى و بر اساس سرنخهايى كه از محيط كار بلددست مىآورند، به اين اقدامها واكنش نشان مى مدهند

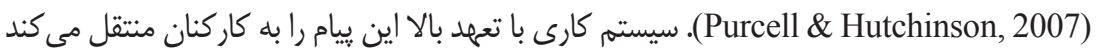

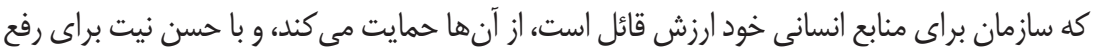
نيازها و خواستههاى آنها تلاش مى كند (Nishii et al., 2008). اخر كاركنان باور كنند كه سازمان با حسن نيت اقدامهايى را اتخاذ مى كند و از آنها حمايت مى كند، أنخاه به سازمان اعتماد مى كنند، جون مطمئن خواهند بود كه مديران قصد سوء استفاده از كاركنان را ندارند.

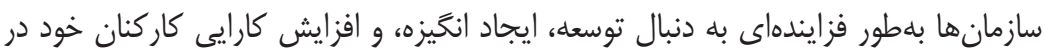
انواع برنامههاى عملياتى، بازار، و منابع انسانى هستند (Buuri, 2015). كاركنان و عملكردشان نقش اساسى در موفقيت هر سازمان ايفا مى كنند، و مديريت عملكرد كاركنان نيز يكى از مهمثرين موضوعها در مديريت سازمان است (Lussier \& Hendon, 2017). بسيارى از سازمانها از مديريت عملكرد كاركنان براى انتخاب، نكمهدارى، ارتقا، اخراج، جبران، برنامهريزى منابع انسانى، و آموزش كاركنان استفاده مى كنند (Haines \& St-Onge, 2012). 
يكى از عمدهرين دغدغههاى مديران در مديريت عملكرد كاركنان در سطوح مختلف سازمان،

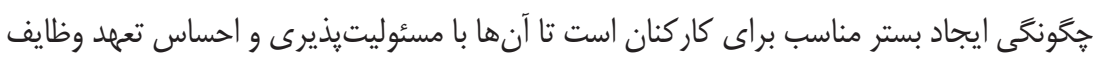
خود را بهدرستى انجام دهند و عملكرد بهيينه داشته باشند (Fu \& Deshpande, 2014). بنابراين، بررسى عوامل موثر بر عملكرد شغلى كار كنان داراى اهميت است. يكى از اين عوامل، الخوى نظام

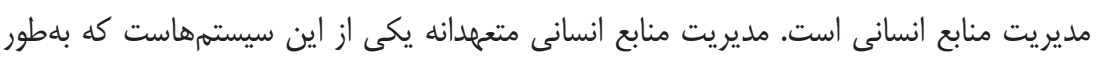
خاص در يى ارتقاى عملكرد فردى كاركنان است (Boon \& Kalshoven, 2014). به سخن

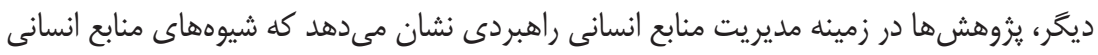

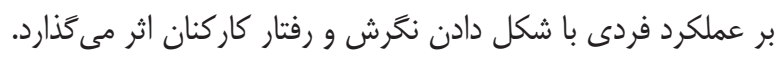
يُروهشخران ارتباط بين انواع مختلف سيستمهاى منابع انسانى و نكرش و وفتار كار كنان، مانند تعهله، رضايت، حمايت اجتماعى، و رفتارهاى شهروندى را بررسى مى كنند (Lepak et al., 2006). بايد در نظر

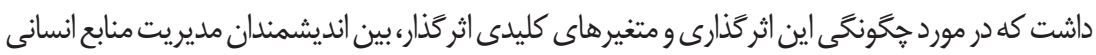

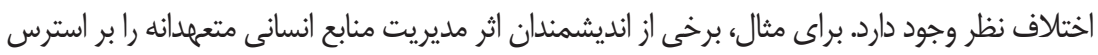

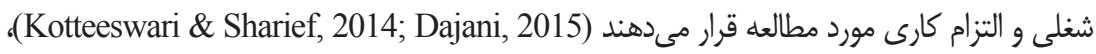

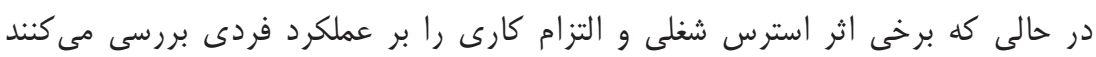

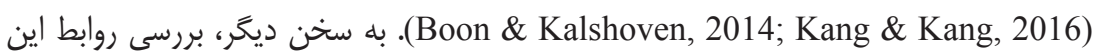

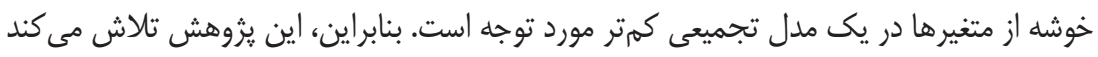

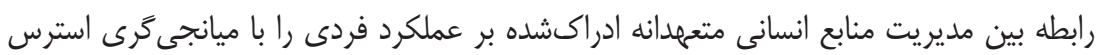

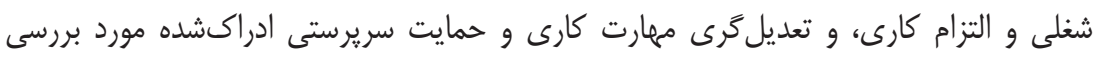

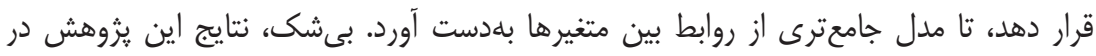

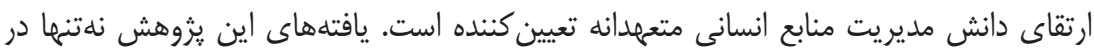
ترميم شكاف يزوهشى اشارهشده اثركذار است، بلكه با مدلسازى مديريت منابع انسانى متعهدانه تئه ادراكشده در سطح فردى، حوزه دانش جديدى را در ادبيات موضوع مطرح مىسازدا.

\section{مبانى نظرى ثزوهش}

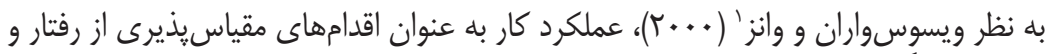

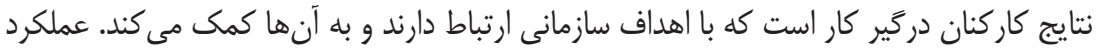

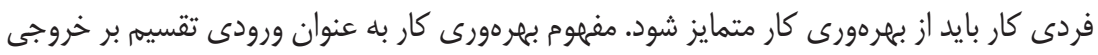


تعريف مىشود. بنابراين، بهروورى كار يك مفهوم ظريفتر از عملكرد كار است. همجنين، مهم

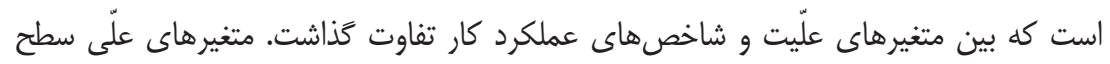

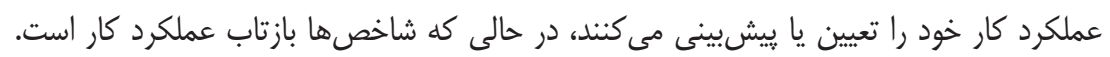

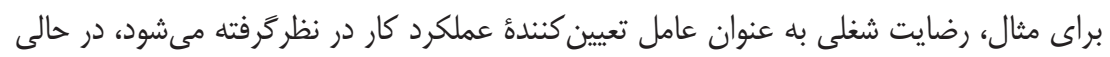

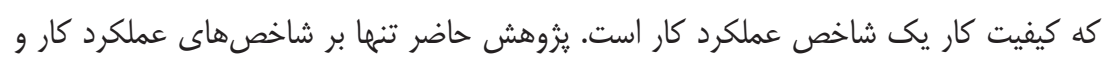

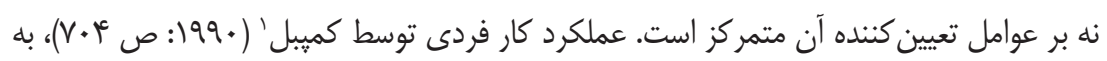

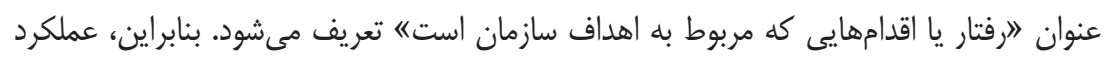

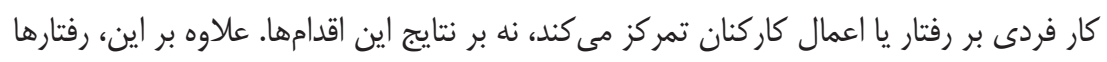

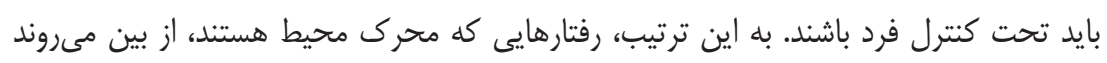

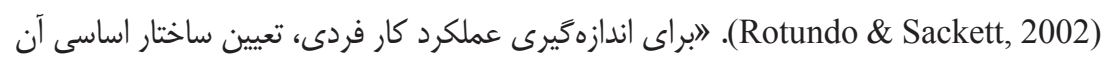

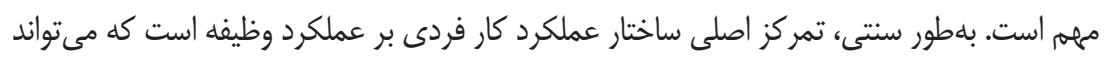

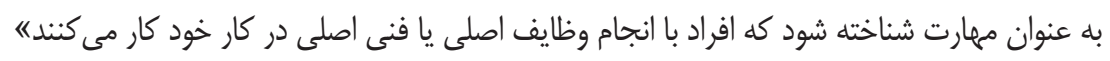

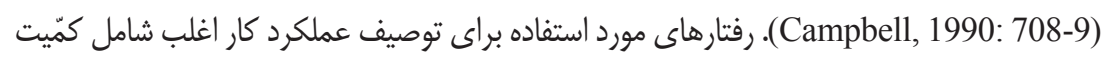
و كيفيت كار، مهارتها و دانش شغلى است (Campbell, 1990; Rotundo \& Sackett, 2002).

\section{سنجش عملكرد فردى}

بر اساس بررسى ادبيات مختلف (2014) 2002; Koopmans et al., 2014

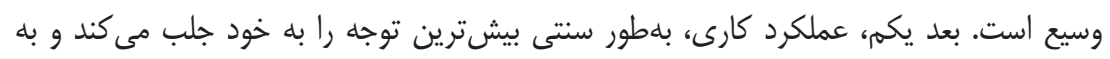

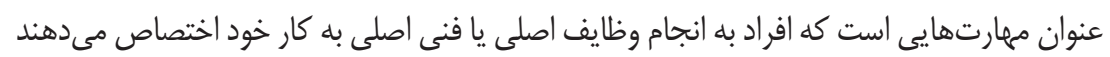

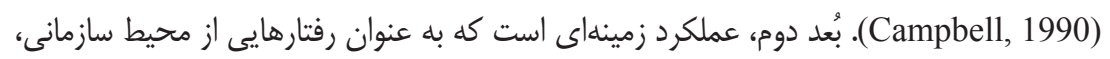

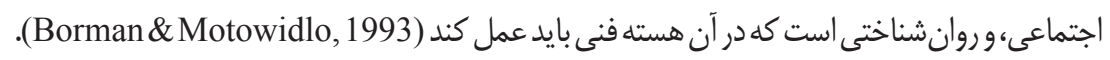

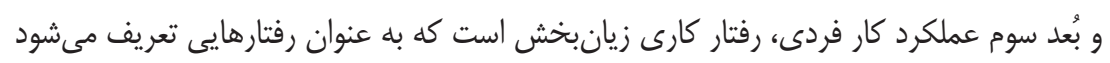

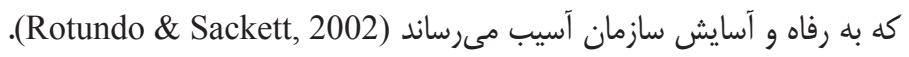

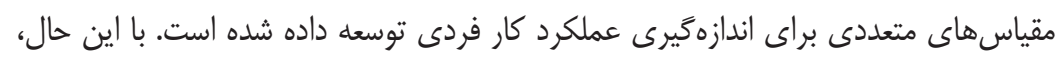

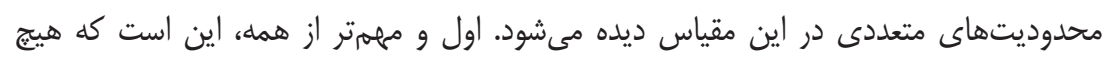

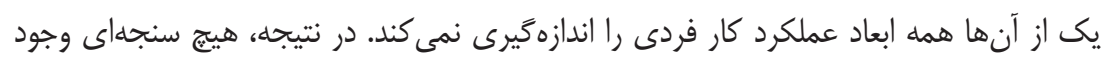

1. Campbell 
ندارد كه طيف كاملى از رفتارهاى فردى را در محل كار شامل شود. دوم، مقياسها اغلب از عملياتهاى مختلف يا مفهومسازىهاى متفاوت يا جمعيتهاى متنوع توسعه مىيابند يا از ابعاد يكسان استفاده مى كنند. اين باعث مىشود كه انتخاب مناسبترين و مرتبطترين مقياس مشكل شود. سوم، مقياس اندازمخيرى ابعاد مختلف اغلب موارد را به نام اقلام ضدتطبيق با هم تداخل

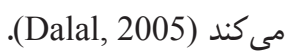

\section{عوامل موثر بر عملكرد فردى}

هرجند متغيرهايى در خصوص عوامل اثركذار بر عملكرد فردى در ادبيات وجود دارد، اما در

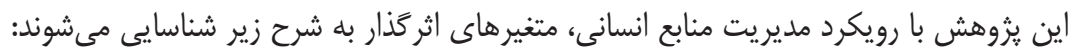

مديريت منابع انسانى متعهدانه ادراككشده

يفر' (1991)، در تبيين مفهوم مديريت منابع انسانى متعهدانه ادراكشده آن را رابطه استخدامى بلندمدت تعريف مى كند كه ويثگى مهم آن احساس امنيت استخدامى است. در جامعترين تعريف،

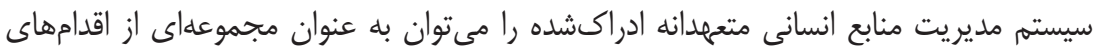

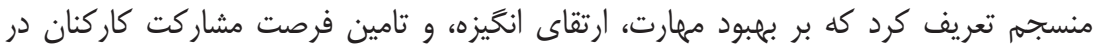

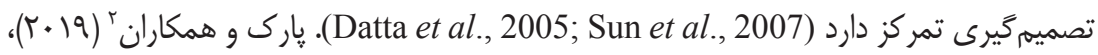

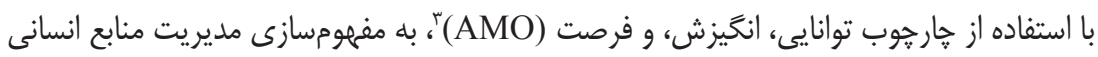

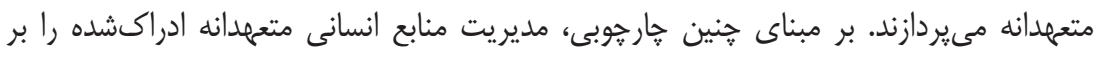

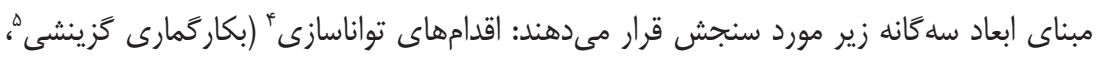

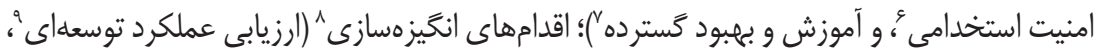

1. Pfeffer

2. Park et al.

3. Ability, Motivation, \& Opportunity-Enhancing

4. Ability-Enhancing Practices

5. Selective Staffing

6. Employment Security

7. Extensive Training and Development

8. Motivation-Enhancing Practices

9. Developmental Performance Appraisals 


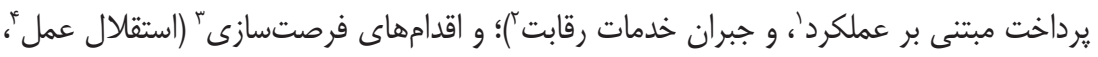

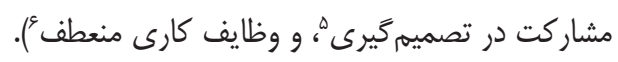

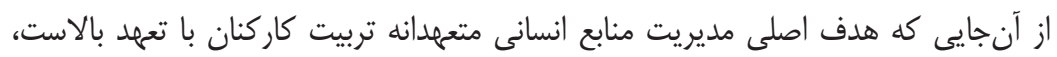
جنين تعهلى در عملكرد فردى منعكس مى شود. بنابراين، تبيين مدلى كه رابطه بين مديريت

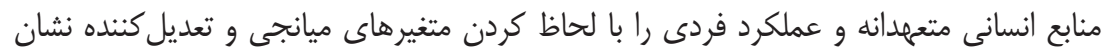

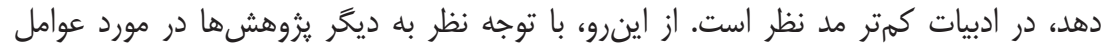

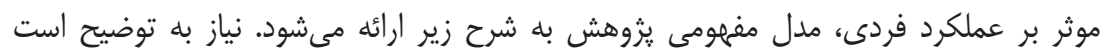

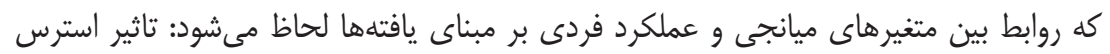
شغلى بر عملكرد فردى (Kotteeswari \& Sharief, 2014)؛ تاثير التزام كارى بر عملكرد فردى في إنى

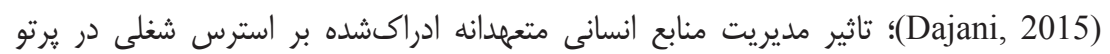
حمايت سريرستى ادار كشده (Kang \& Kang, 2016)؛ و تاثير مديريت منابع انسانى متعهدانه بر التزام كارى در يرتو مهارت كارى (Boon \& Kalshoven, 2014).

يزوهشكَران مديريت منابع انسانى استدلال مى كنند كه مديريت منابع انسانى، بلويزهه مديريت منابع انسانى با تعهد بالا، همانطور كه كاركنان در توسعه بلندمدت سرمايهكذارى مئكى كنند، مىتواند بر نكرش كاركنان از طريق ساختن كارمندان خوب، شاد، و ير انرزى در محل كار تاثير

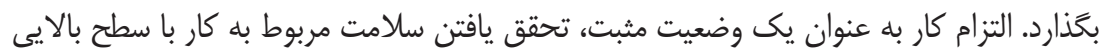
از انرزى تعريف مىشود، و به عنوان مخالف مثبت فرسودگى ديده مىشود. همجنين، مشاركت در

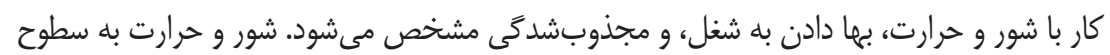

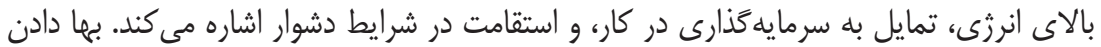
به شغل به دخالت قوى در يك كار، و يك حس مهمه، شور و شوق، الهام، غرور و خالش اشاره

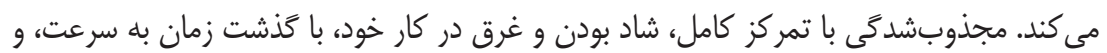

داشتن مشكلات از خود جدا از كار توصيف مىشود (Schaufeli et al., 2001).

1. Performance-Based Pay

2. Competitive Compensation

3. Opportunity-Enhancing Practices

4. Autonomy

5. Participation in Decision Making

6. Flexible Work Assignments 


\section{تسلط كارى}

نظريه حفاظت از منابع بيان مى كند كه علاوه بر منابع سازمانى، كاركنان ممكن است منابع

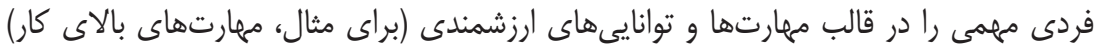

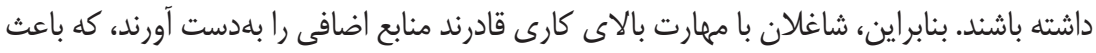

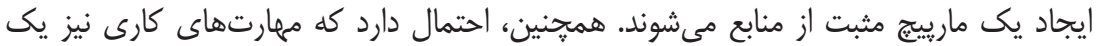

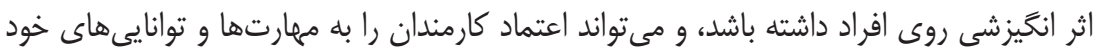
اطمينان دهد. بنابراين، كاركنانى كه داراى مهارت بالا هستند ممكن است بتوانند منابع بيشترى نسبت به كار كنانى كه مهارت كمترى دارند، بهدست آورند (Boon \& Kalshoven, 2014).

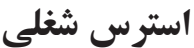

سلامت جسمى و روانى اعضاى سازمان براى موفقيت بسيار مهم است، زيرا بهرهورى سازمان

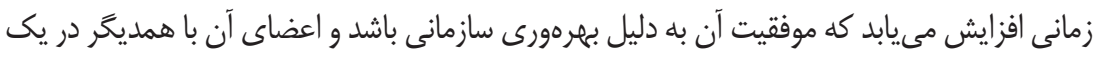

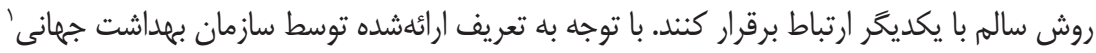

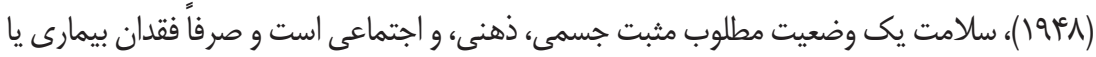
ضعف نيست. هنگَامى كه سلامت يك كاركَ به دليل استرس بيش از حد كاهش مي يابد، اثرش نهتنها

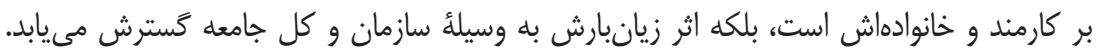
احر كاركنان يك سازمان به خاطر استرس شغلى مزمن، تجمعى، و بىوقفه موفق به حفظ سلامت

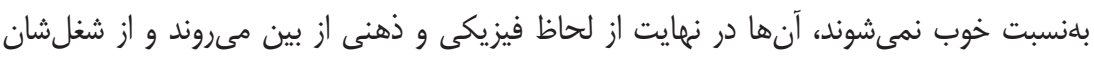
رضايت ندارند و در نهايت بر عملكرد سازمان اثر منفى مى كذارند (Kang \& Kang, 2016).

\section{حمايت سريرستى ادراكتشده}

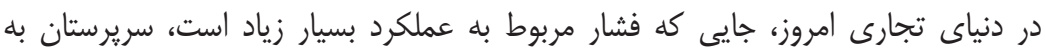

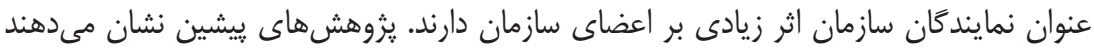
كه در مقايسه با حمايت اجتماعى پايينتر توسط ناظران و همكاران بالاتر، افزايش كارايى كاهش مىيابد (Brough \& Frame, 2004; Monnot \& Beehr, 2014). به همين دليل اين امر بالئ

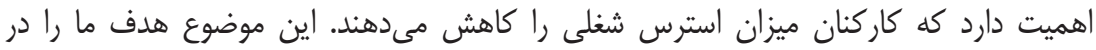

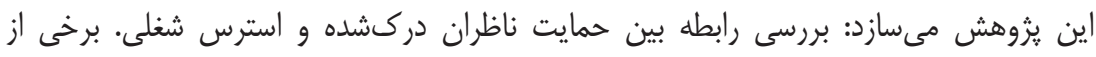


يزوهشها، ييشنهاد مى كنند كه حمايت سريرستان و يشتيبانى سازمانى در كشده مىتواند بر رابطه بين شيوههاى مديريت منابع انسانى و استرس شغلى اثر بخذارد (Brough \& Frame, 2004) (Monnot \& Beehr, 2014; Topcic et al., 2016; Etzion, 1984 (1999)، نيز ييشنهاد مى كنند حمايت اجتماعى از سريرستان نهتنها باعث كاهش استرس شغلى ولى

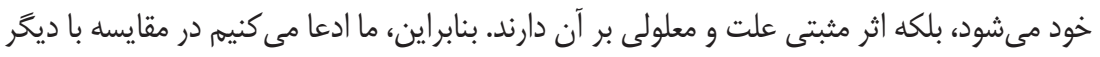

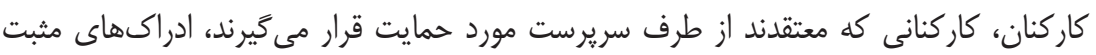

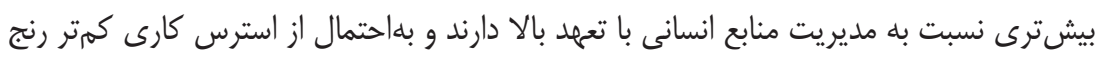

مىبرند (Kang \& Kang, 2016).
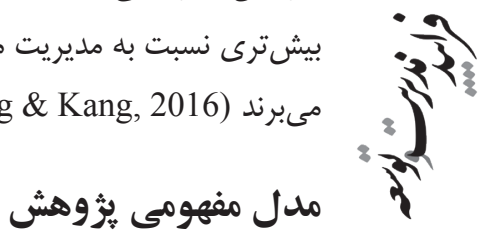

با توجه به مبانى نظرى ييشگفته، مدل مفهومى يثوهش به شرح نمودار ( (1) ارائه مىشود.

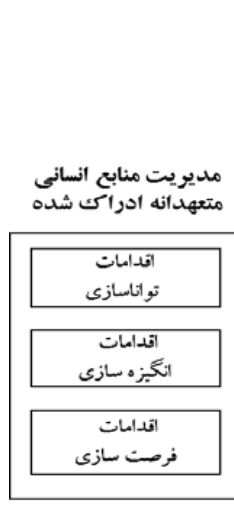

PHC-HRM

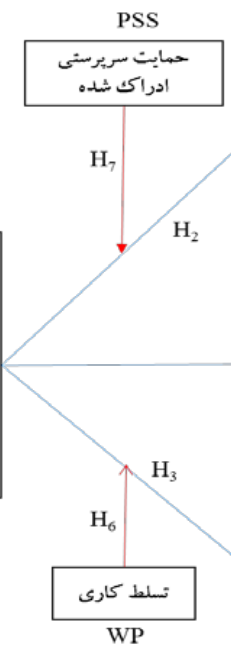

نمودار ا: مدل مفهومى يخوهش

فرضيههاى يزوهش

با توجه به مدل مفهومى يزوهش، فرضيههاى بثوهش به صورت زير تدوين مىشوند: فرضيه (: مديريت منابع انسانى متعهدانه بر عملكرد فردى اثر مثبت و معنادار دارد. 
فرضيه ז': مديريت منابع انسانى متعهدانه بر استرس شغلى اثر مثبت و معنادار دارد.

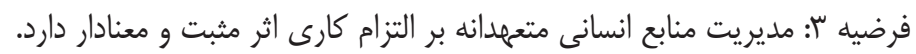

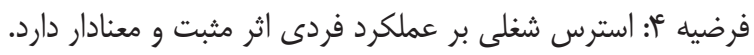

فرضيه ه: التزام كارى بر عملكرد فردى اثر مثبت و معنادار دارد.

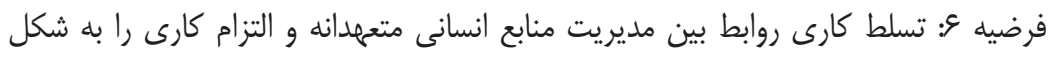

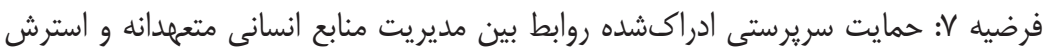
شغلى را به شكل مثبت و معنادارى تعديل مى كند.

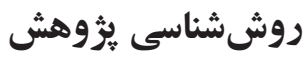

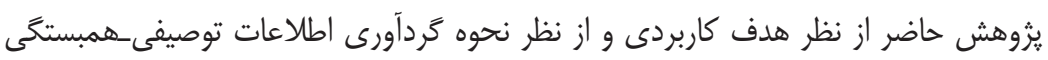
است. با توجه به مدل مفهومى اين يزوهش كه به صورت ارتباط ساختارى بين سازههايى است كه

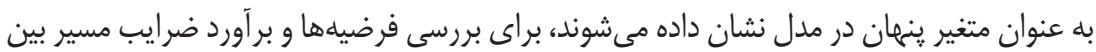

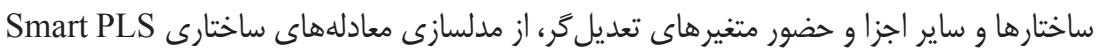

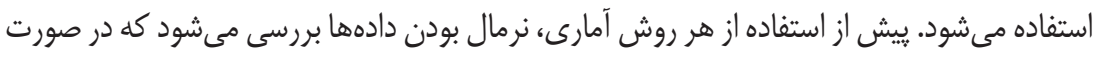

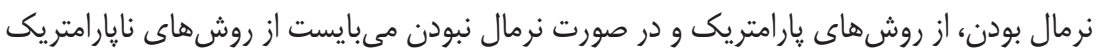

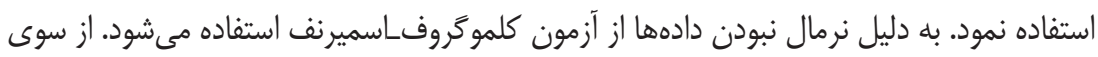

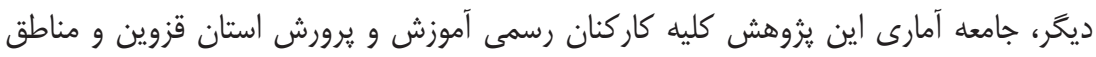

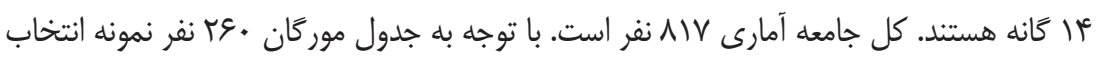

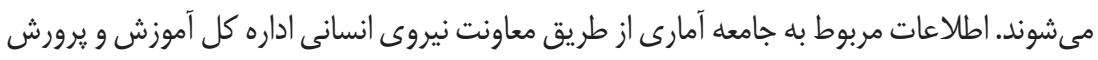

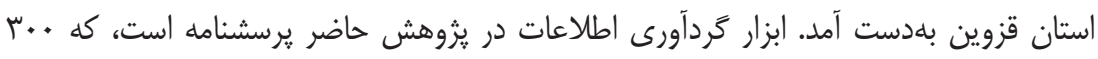

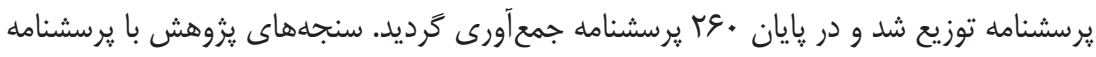

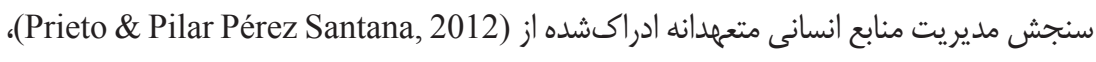

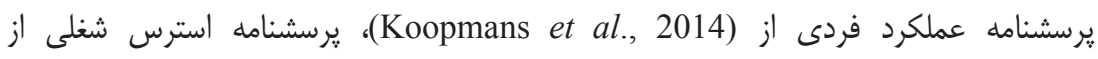
(Keller, 1984; Kang \& Kang, 2016)

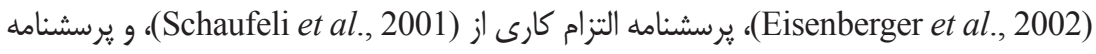
تسلط كارى از (Van Dyne \& LePine, 1998) كَردآورى مى شود. نماكر هاى سنجش متغيرها در جدول (1) منعس مى شود. 
جدول ا: ابعاد، مولفهها، و نماكرهاى سنجش متغيرهاى بثزوهش

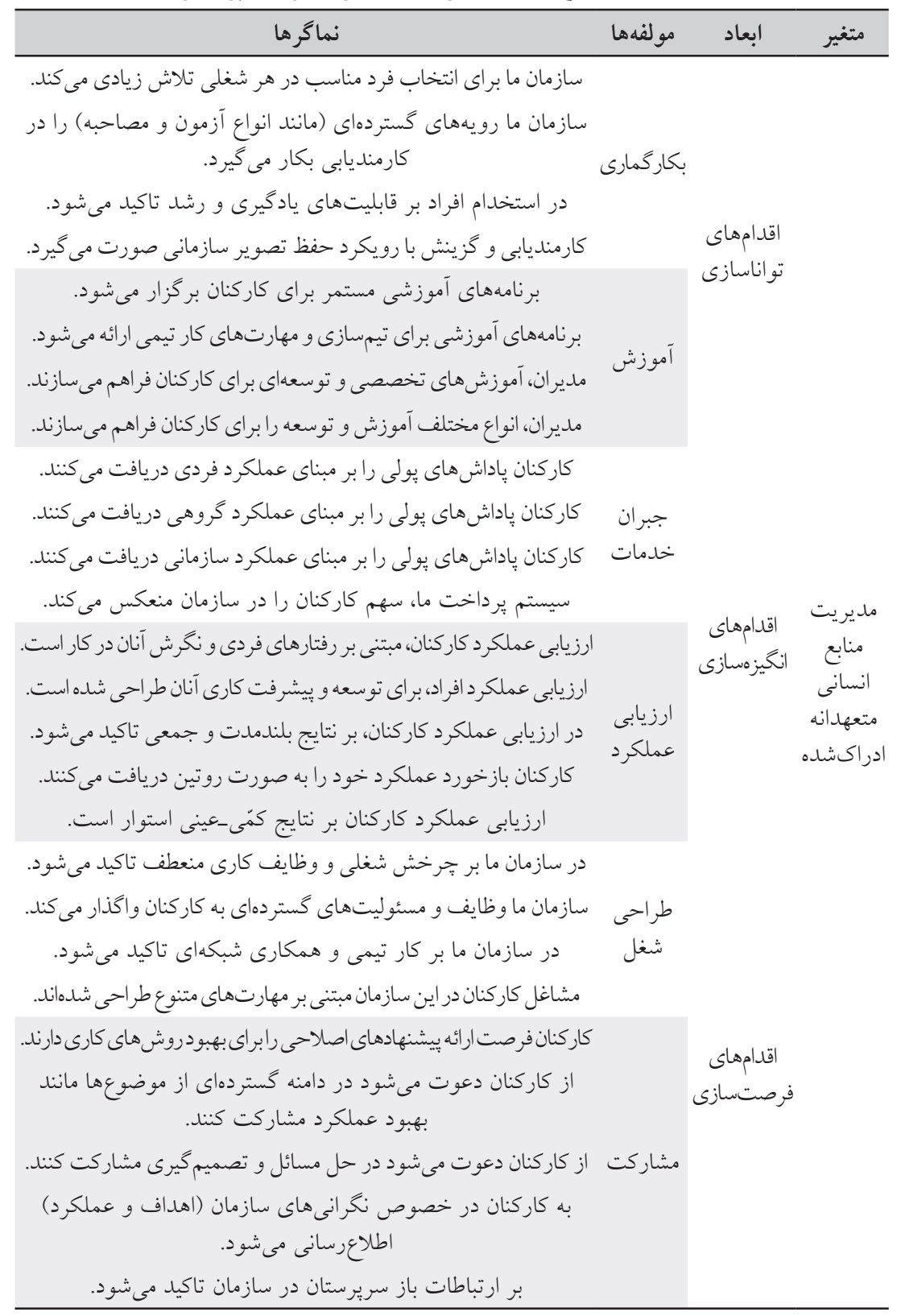


ادامه جدول ا: ابعاد، مولفهها، و نماترهاى سنجش متغيرهاى يثوهش

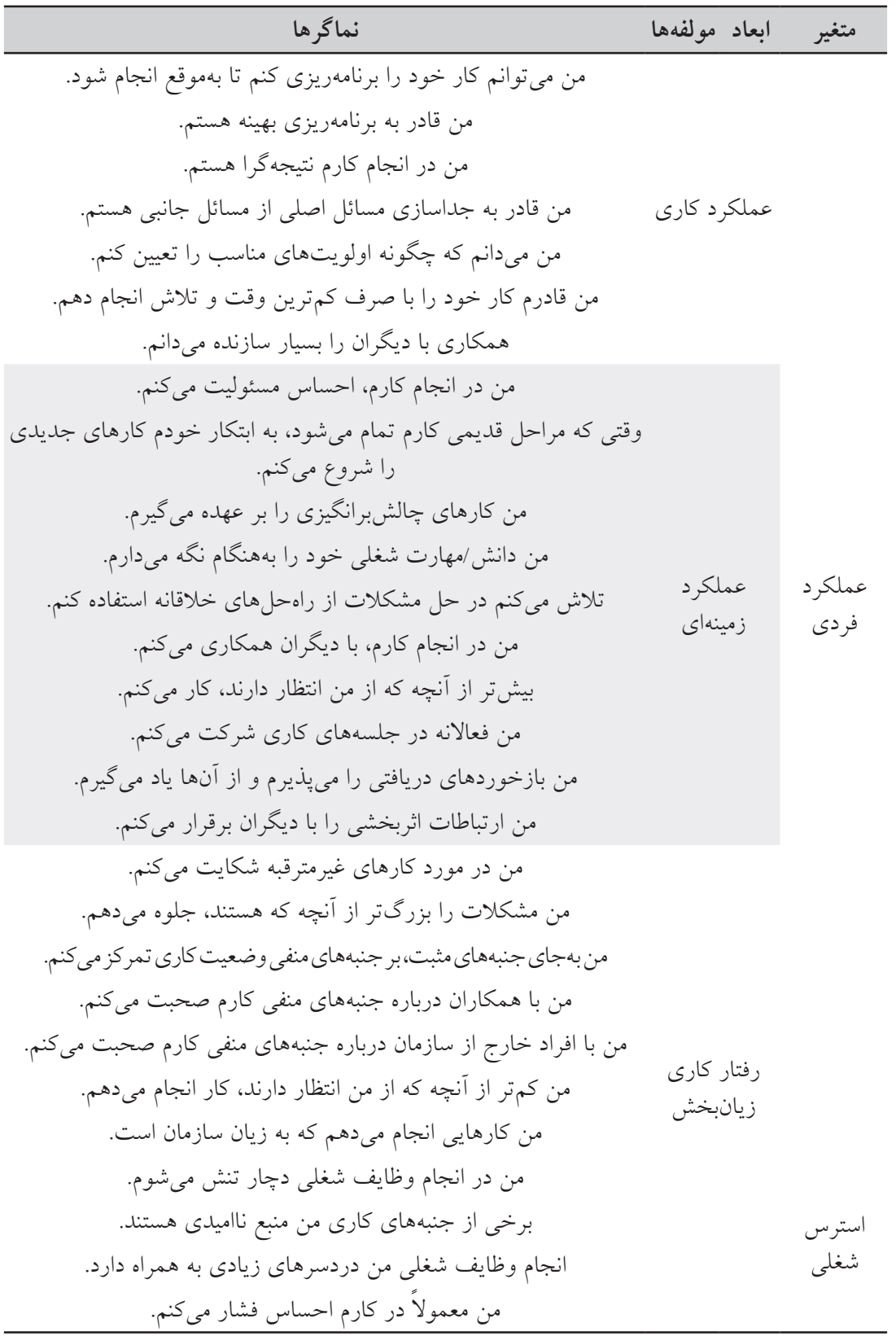


ادامه جدول 1: ابعاد، مولفهها، و نماكرهاى سنجش متغيرهاى بزووهش

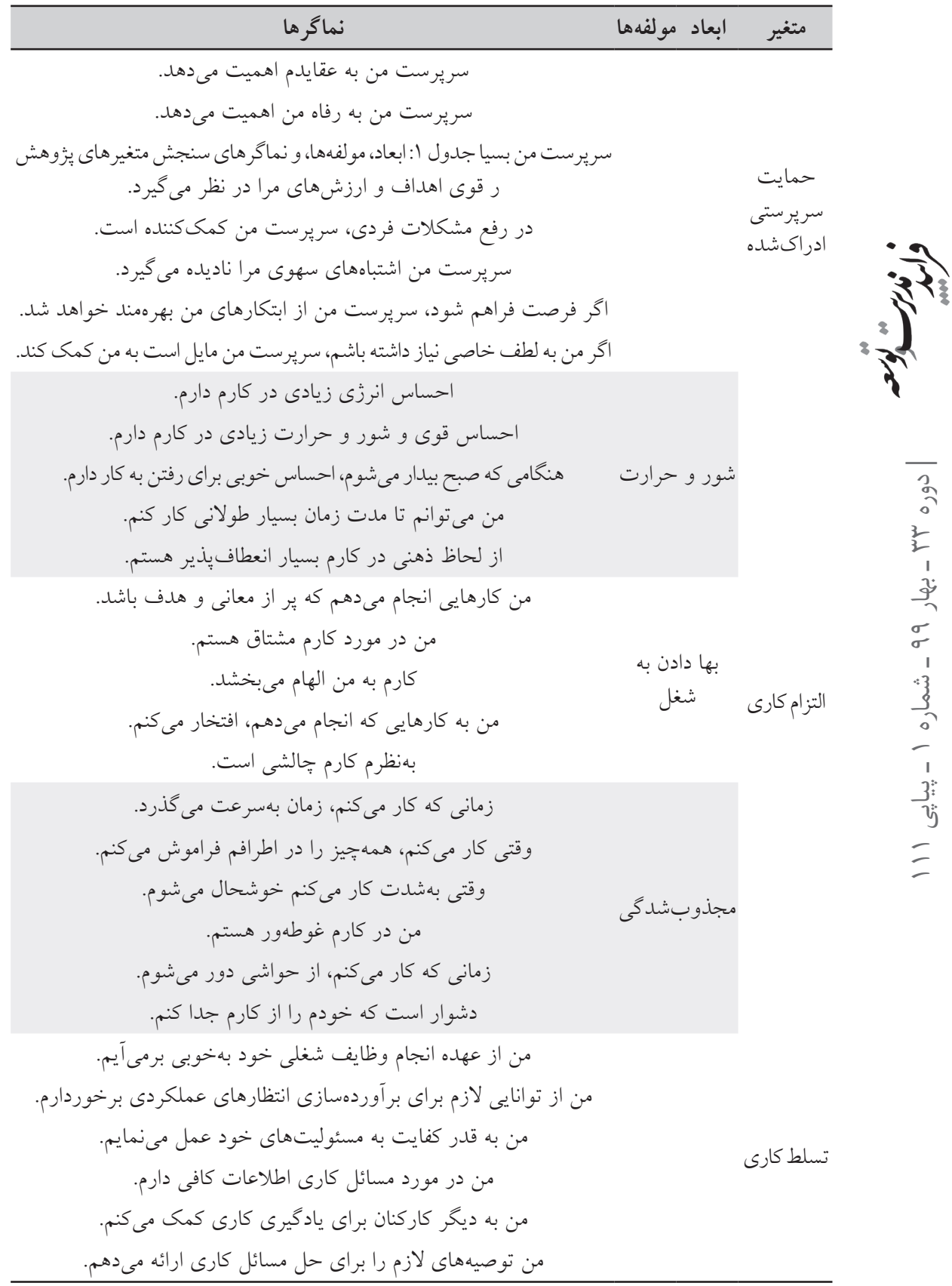


بررسى بإيايى تمامى متغيرهاى برسشنامه نشان مىدهد كه آلفاى كرونباخ آنها بالاتر از / IV •

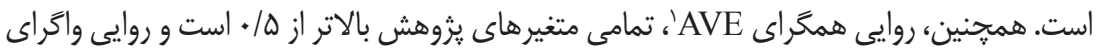

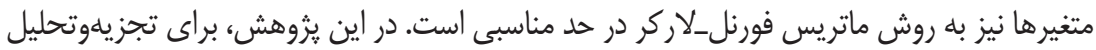
دادهها، مدلسازى معادلههاى ساختارى به روش حداقل مربعات جزئى؟ (PLS) مورد استفاده قرار

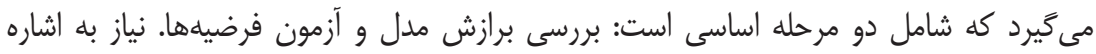

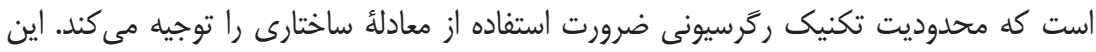
محدوديتها عبارتاند از ا. ناتوانى در محاسبه روابط غيرمستقيم در مدل؛ ז. اندازمكيرى نكردن

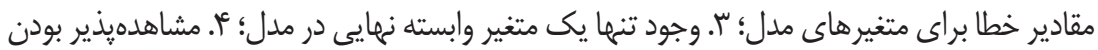
كليه متغيرهاى مدل؛ و ه. نبود معيارى براى ارزيابى مدل. در PLS دو مدل آزمون مىشود: مدلهاي

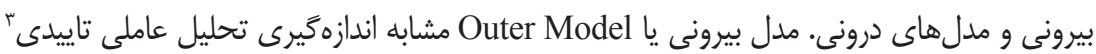
(CFA)، مشابه تحليل مسير در مدلهاى معادلههاى ساختارى است. Inner Model

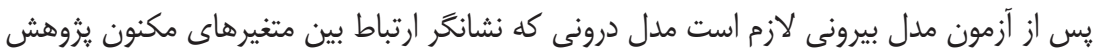

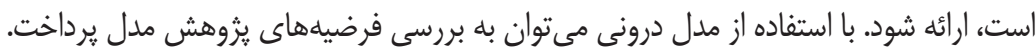

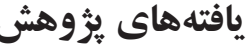
براى بررسى فرضيههاى يزوهشى ابتدا ضرايب مسير استانداردشده را نمايش مىدهيم.

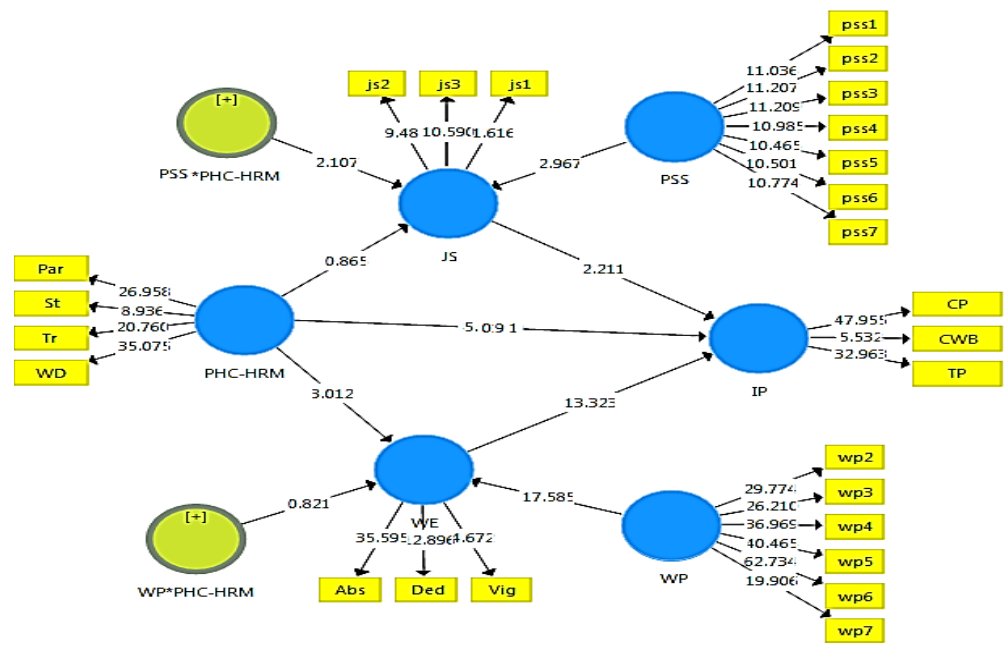

نمودار r: ضرايب مسير استانداردشده مدل

1. Average Variance Extracted

2. Partial Least Square

3. Confirmatory Factor Analysis 
در نمودار (T)، PHC-HRM معرف مديريت منابع انسانى متعهدانه ادراكشده، IP عملكرد

فردى، WP تسلط كارى، PSS حمايت سريرست، JS استرس شغلى، و WE التزام كارى است.

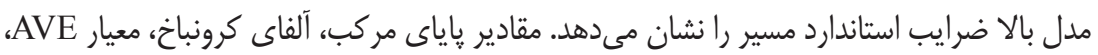
و ضريب تعيين مدل در جدول (T) آمده است.

جدول r: مقادير آلفاى كرونباخ، هايايى مركب، AVE، و R متغير هاى مكنون يزوهش

\begin{tabular}{|c|c|c|c|c|}
\hline آلفاى كرونباخ & R Square & بايايى مر كب & AVE & متغير ها \\
\hline$\cdot / K Y$ &.$/ 419$ & $\cdot / 01$ & $\cdot / 09$ & عملكرد فردى \\
\hline$\cdot / \wedge \Delta$ & $\cdot / \& V Q$ & $\cdot / 91$ & $\cdot / \mathrm{N}$ & 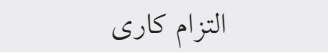 \\
\hline .199 & - & $\cdot / 9 V$ & $\cdot / \wedge$ & حمايت سريرستى ادراكشده \\
\hline$\cdot / \mathrm{V} 9$ & $\cdot / \cdot v i$ & $\cdot / 19$ & $\cdot|9|$ & استرس شغلى \\
\hline$\cdot / M \Lambda$ & - & $\cdot / 19$ & $\cdot 194$ & مديريت منابع انسانى متعهدانه \\
\hline.$/ 91$ & - & . $/ 94$ & .199 & تسلط كارى \\
\hline
\end{tabular}

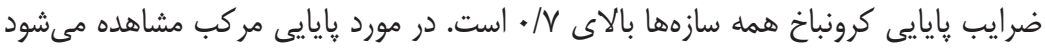

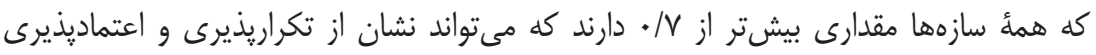
يرسشنامه باشد.

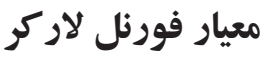

جدول rا: ماتريس فورنل-لاركر براى روايع واكرا

\begin{tabular}{|c|c|c|c|c|c|c|}
\hline لط كارى & منابع انسانى & شغلى & سرايرستى & التزام كارى & فردى علكرد & \\
\hline & & & & & $\cdot / \mathrm{VV}$ & عملكرد فردى \\
\hline & & & & $\cdot / M \Lambda$ & .194 & التزام كارى \\
\hline & 4 & & $\cdot / 9$ & $\cdot / \mu \Lambda$ & $\cdot 149$ & حمايت سريرستى ادراكشده \\
\hline & & $\cdot$ NA & $-\cdot / T Y$ & $-\cdot / T y$ & $-\cdot / 79$ & استرس شغلى \\
\hline & $\cdot / \mathrm{Na}$ &.$- / 19$ & $\cdot / 4 T$ & $\cdot / 19$ &.$/ 19$ & مديريت منابع انسانى متعهدانه \\
\hline$\cdot|\Lambda|$ & $\cdot / 1$ & -.110 & $\cdot / r 1$ & .190 & .199 & تسلط كارى \\
\hline
\end{tabular}


مجذور مقدار AVE در قطر اصلى قرار مى گيرد و جون اين مقدار از تمامى همبستگىهاى

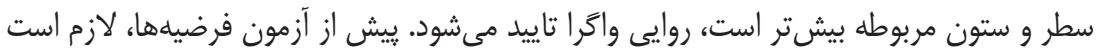

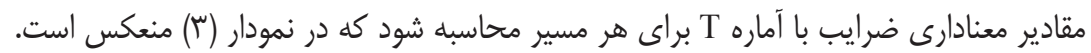

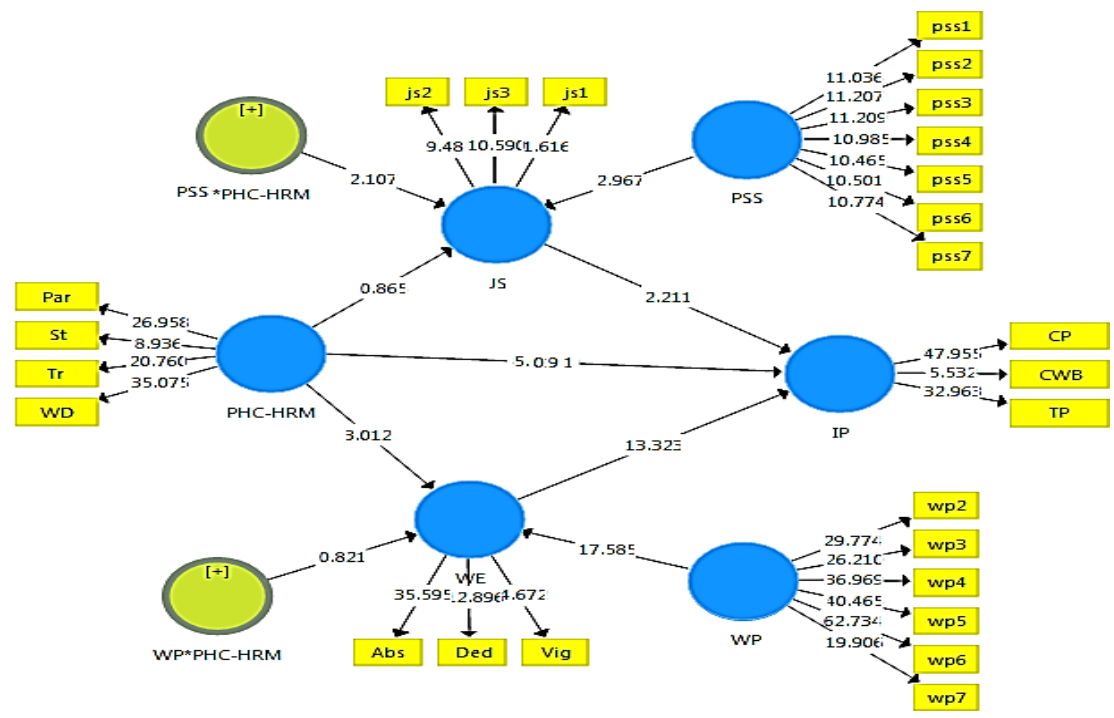

نمودار بّ: مدل ساختارى در حالت معنادارى

اكر ضريب مسيرى بيشتر از عه/ اباشد، آنغاه آن ضريب در سطح خطاى ه درصد معنادار

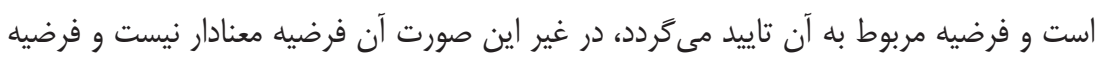
رد مىشود.

جدول †: ضرايب مسير و مقادير t در مدل ساختارى

\begin{tabular}{|c|c|c|c|c|}
\hline فرضيه & 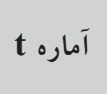 & استاندارد اف اف & 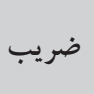 & 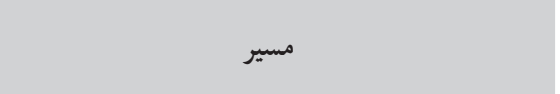 \\
\hline تاييد & $0 / \cdot 9$ &.$/ 44$ & $\cdot / T Y Q$ & مديريت منابع انسانى متعهدانه ـ-ه> عملكرد فردى \\
\hline رد & $\cdot / \wedge 9$ & $\cdot / \cdot \mathrm{VV}$ & $-\cdot / \cdot v$ & مديريت منابع انسانى متعهدانه ـــــ استرس شغلى \\
\hline تاييد & $\mu / \cdot 1$ & $\cdot / \cdot k$ & $\cdot / 10$ & 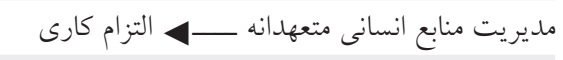 \\
\hline تاييد & $T / T_{1}$ & $\cdot / \cdot \wedge r$ & $-\cdot / 1 r$ & 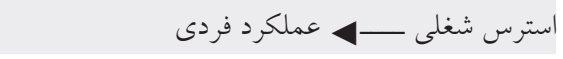 \\
\hline تاييد & Ir/Mr & $\cdot / \cdot \Delta V$ & $\cdot 109$ & 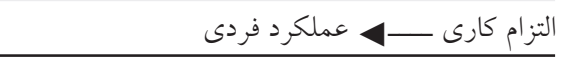 \\
\hline
\end{tabular}




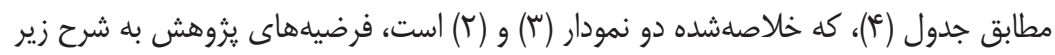

$$
\text { مورد آزمون قرار مى خيرد. }
$$

فرضيه ا: مديريت منابع انسانى متعهدانه ادراكشده بر عملكرد فردى درى اثر مثبت و معنادار دارد.

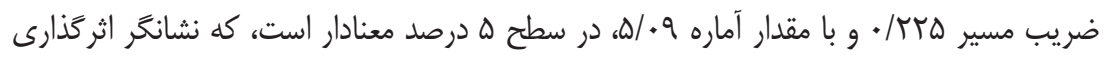

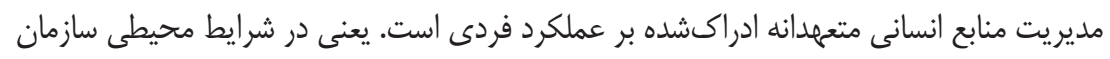

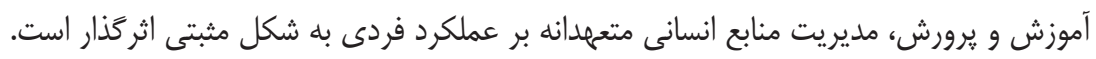

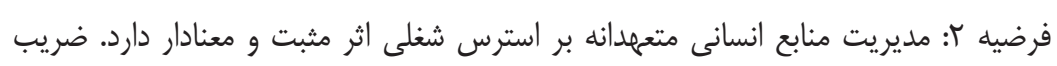

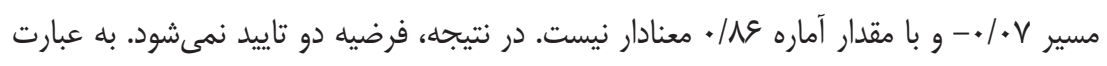

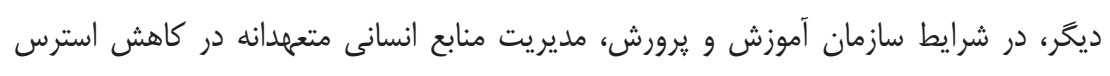

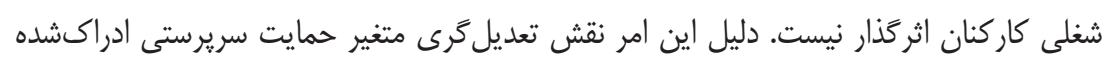

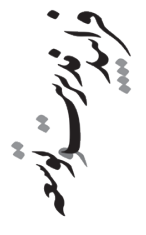

فرضيه سّ: مديريت منابع انسانى متعهدانه بر التزام كارى اثر مثبت و معنادار دارد. ضريب مسير

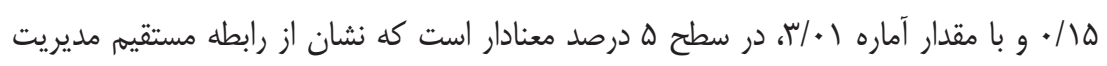

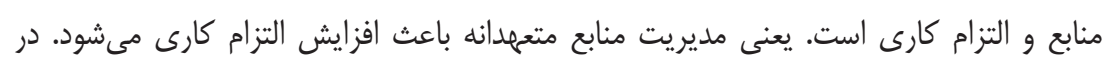
نتيجه فرضيه سه تاييد مىشود.

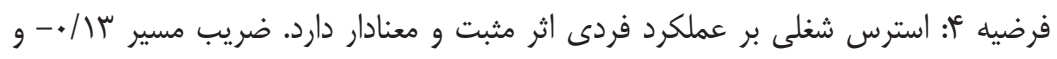

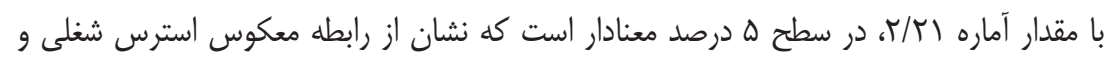

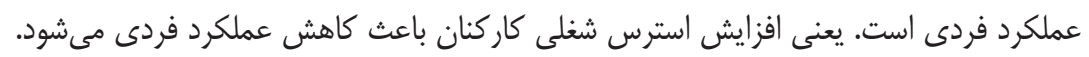

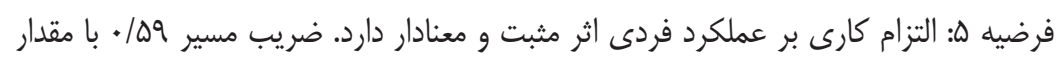

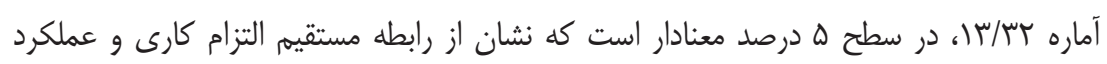

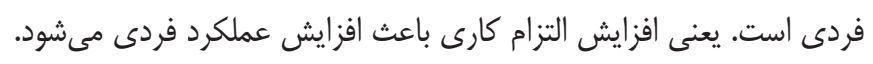

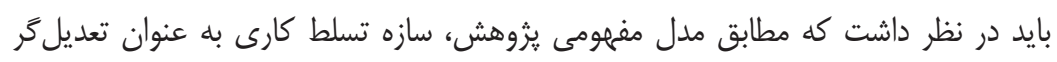

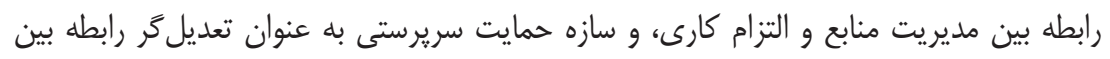

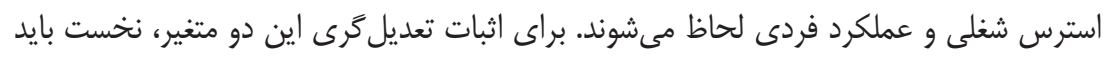

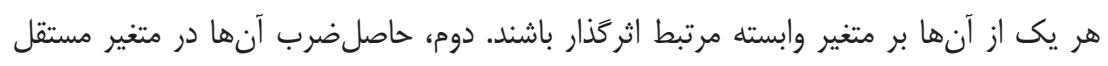

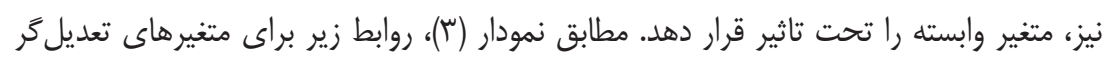
بdدست آمده است. 
جدول ه: ضرايب مسيرها و آماره t متغيرهاى تعديل كر در مدل ساختارى

\begin{tabular}{|c|c|c|c|c|}
\hline 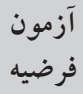 & $\mathbf{T}$ & انحتاندارد إن & 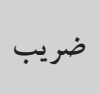 & مسير \\
\hline تاييد & $\mid V / 0 \Lambda$ & $\cdot / \cdot$ kq $^{4}$ & .194 & تسلط كارى —ــــ التزام كارى \\
\hline ני & $\cdot / A Y \mid$ & $\cdot 1 \cdot 49$ & $-\cdot / \cdot k \cdot$ & مديريت منابع انسانى متعهدانه × تسلط كارى ـــــــــام التزام \\
\hline تاييد & T/99 & $\cdot / \cdot \wedge \mathrm{V}$ & $-\cdot / T r$ & 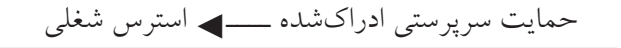 \\
\hline تاييد & $r / l \cdot V$ & $\cdot / \cdot V Q$ &.$- / 111$ & 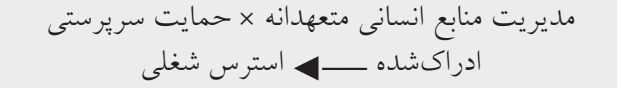 \\
\hline
\end{tabular}

فرضيه ع: تسلط كارى روابط بين مديريت منابع انسانى متعهدانه و التزام كارى را به شكل

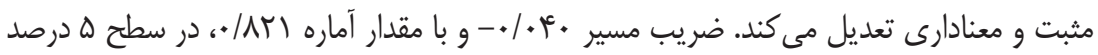

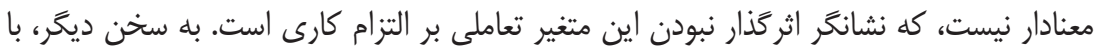
وجود اينكه تسلط كارى بر التزام كارى اثرگذار است، اما اين متغير در رابطه بين مديريت منابع بردير انسانى متعهدانه ادراكشده و التزام كارى در نقش تعديل كننده ظاهر نمى نودا. فرضيه V: حمايت سريرستى ادراكشده روابط بين مديريت منابع انسانى متعهدانه و استرش شغلى را به شكل مثبت و معنادارى تعديل مى كند. همانطور كه در جدول (ه) ديده مىشود، حمايت سريرستى بر استرس شغلى اثركذار است. در ضمن، ضريب مسير بين حمايت سريرستى

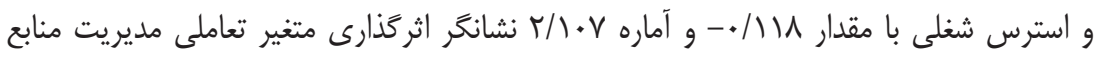
انسانى متعهدانه و حمايت سريرستى بر استرس شغلى است. با توجه به منفى بودن ضريب مسير،

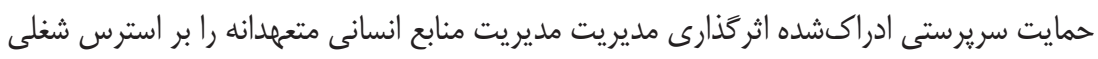

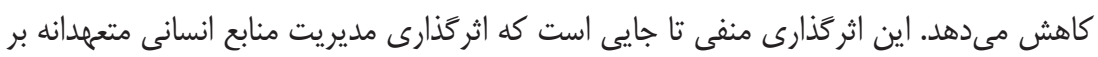

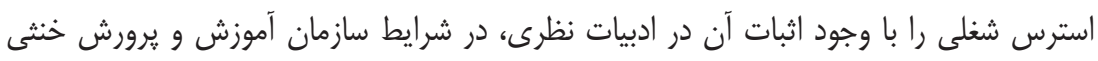
مى كند.

\section{برازش مدل ساختارى}

در نرمافزار PLS معيار مناسب بودن مدل، ضريب تعيينى است كه براى مدل ارائه مىشود و تعبيرى مشابه رگرسيون دارد، يعنى هرجه ضريب تعيين به يك نزديكتر باشد، مدل قوىتر عمل مى كند (البته قدرت مدل بستخى به ابزار مناسب يعنى يرسشنامه مناسب دارد). مقدارهاى 
توصيهشده براى ضريب تعيين در مدلهاى ساختارى سץ/· براى مدل متوسط، و ع\&/• براى مدل

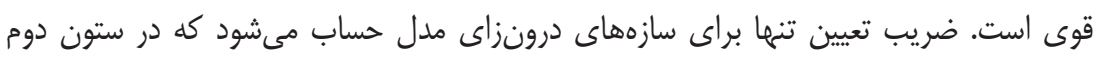

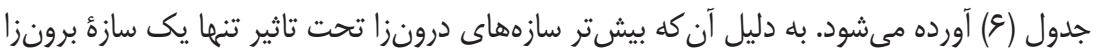

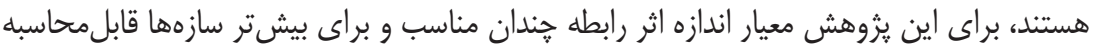

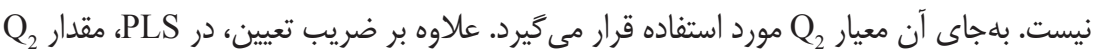
وجود دارد كه قدرت بيشيينى مدل را نشان مىدهد.

جدول 9: شاخصهاى نيكويى برازش مدل

\begin{tabular}{|c|c|c|}
\hline سازهها & ضريب تعيين & Q معيار \\
\hline عملكرد فردى & . MTt &.$/ 41$ \\
\hline التزام كارى & - IFVA & L \\
\hline استرس شغلى & $\cdot 1 \cdot V^{c}$ & .1 .9 \\
\hline
\end{tabular}

با توجه به جدول (()، ضريب تعيين عملكرد فردى و التزام كارى در حد مناسب و قابلقبول است، و استرس شغلى كمى بايينتر از حد مناسب است. معيار Q نيز كه مقدار توصيهشده آن بيشتر

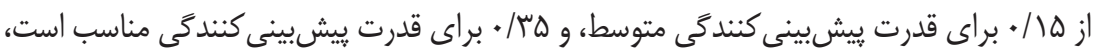
براى سازه عملكرد فردى و التزام كارى در حد مناسبى است، يعنى قدرت يِيشبينى كنندگى اين

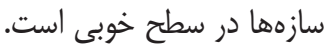

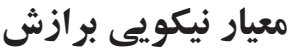

معيار نيكويى برازش تنها معيار براى سنجش برازش كلى مدلهاى معادلهاى ساختارى است

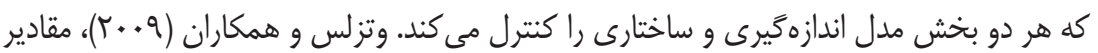

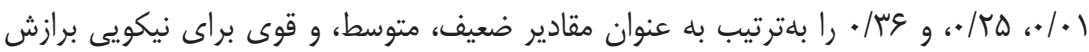
كلى مدل تعيين مىنمايند. معيار GOF در قالب فرمول زير محاسبه مى مشود:

$\mathrm{GOF}=\sqrt{\overline{\text { Communalities }} * \mathrm{R}^{2}}$

ميانكَين مقادير اشتراكى سازهاى مرتبه اول مدل يُوهش كه همان مقادير AVE سازههاست،

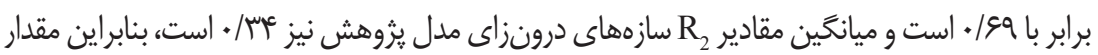


معيار GOF عدد ^^^/ • بهدست مى آيد، و از آنجا كه بيشتر از مقدار ملاك عَ/• است، نشاندهنده

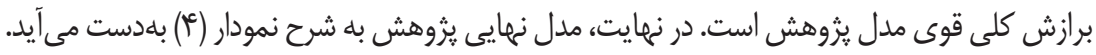

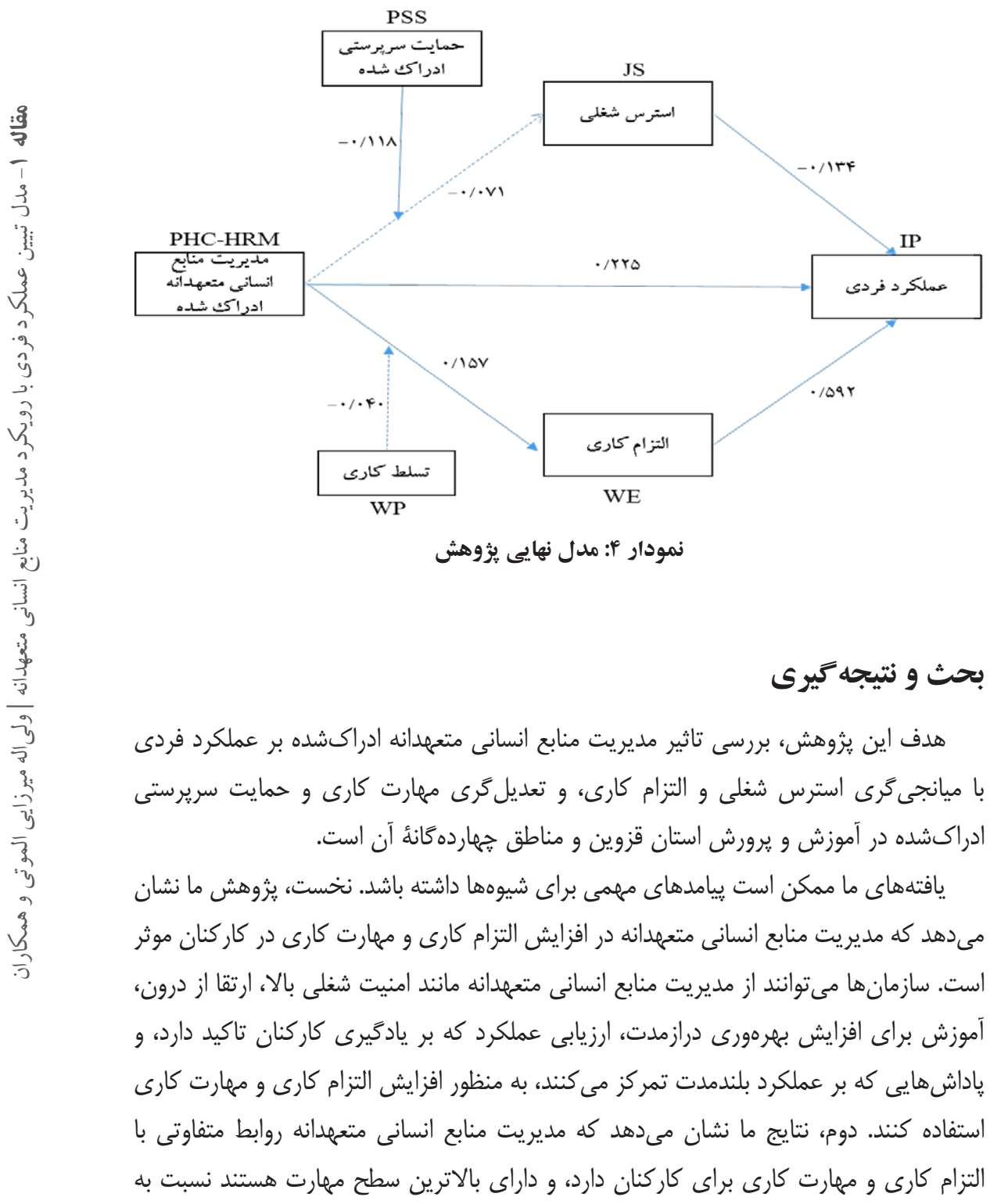


كسانى كه مهارت كمترى دارند. به نظر مىرسد كه مديريت منابع انسانى متعهدانه، بهطور ويزه

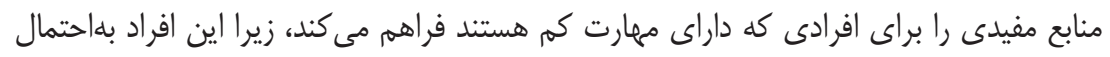

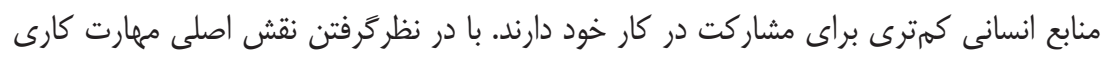
در مديريت منابع انسانى متعهدانه، سازمانها ممكن است در سطوح مهارتهاى كارى كارى، خود را رادر

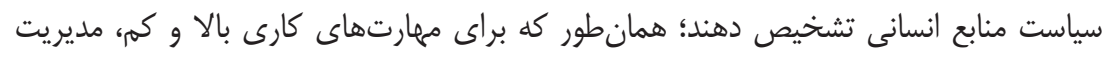

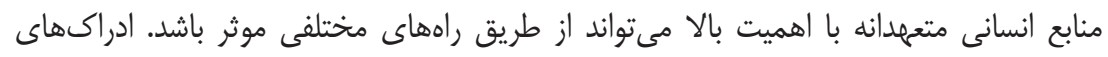

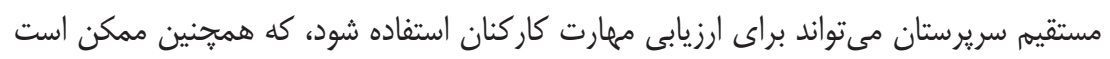

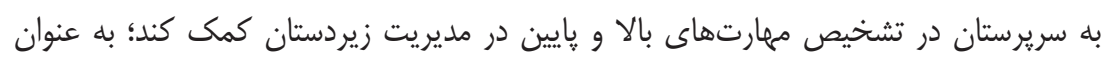

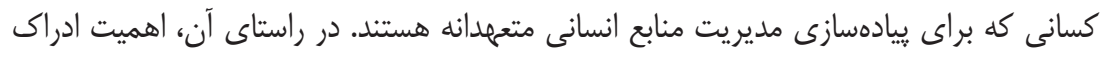

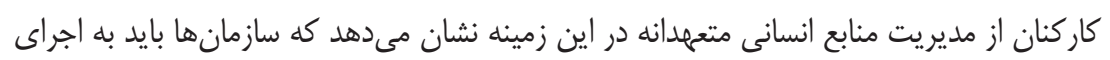

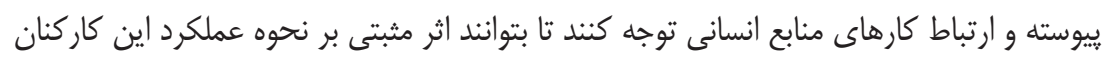

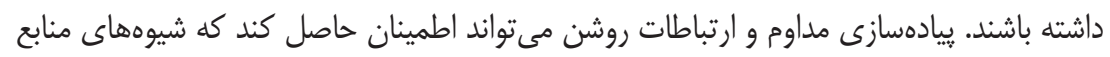

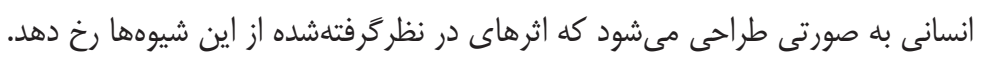

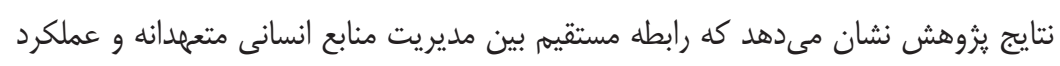

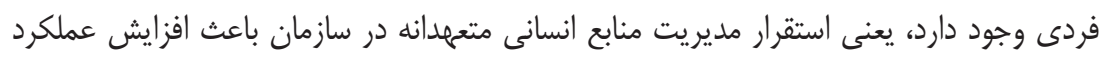

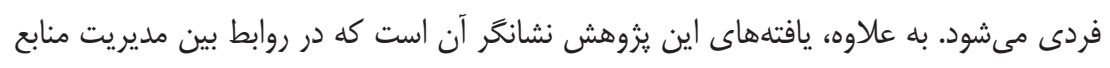

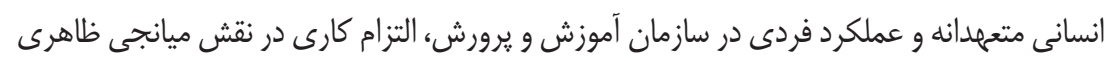

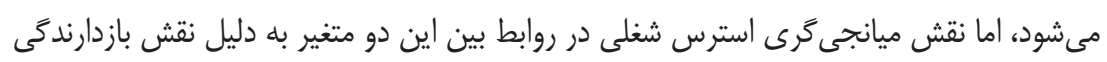

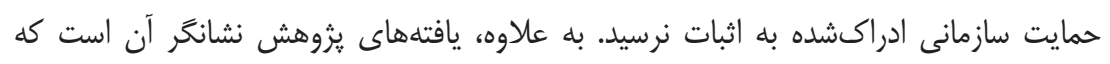

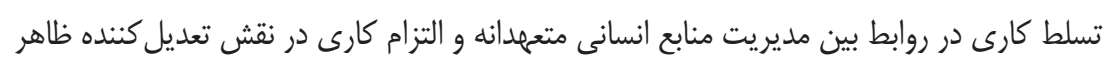

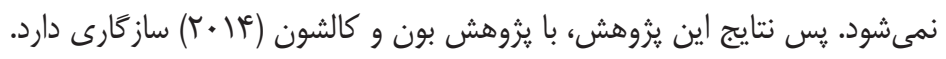

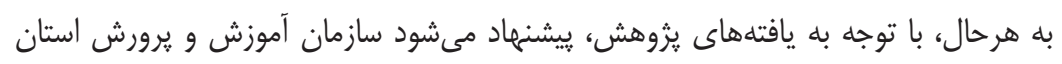
قزوين براى ارتقاى عملكرد فردى كاركنان خود در استقرار جامع مديريت منابع انسانى متعهدانه بـانه

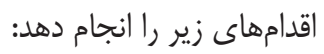
ا. اقدامهاى تواناسازى: كَزينش كاركنان مبتنى بر شايستهسالارى، و آموزش و توسعه آنان

$$
\text { مبتنى بر نيازهاى راهبردى سازمان؛ }
$$

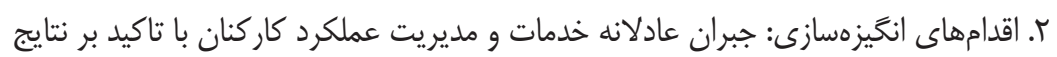

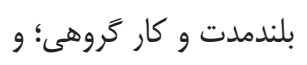


r. اقدامهاى فرصتسازى براى كاركنان: طراحى شغل مبتنى بر كار تيمى و همكارى شبكهاى

$$
\text { و استقرار تصميمگيرى مشار كتى. }
$$

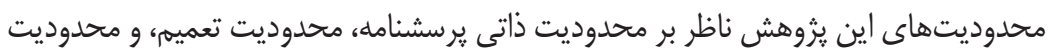

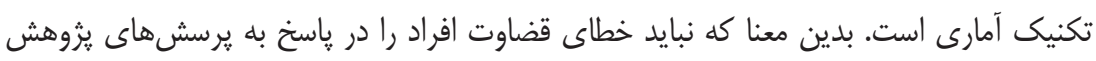

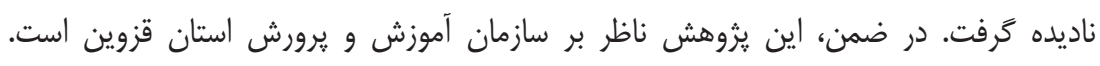

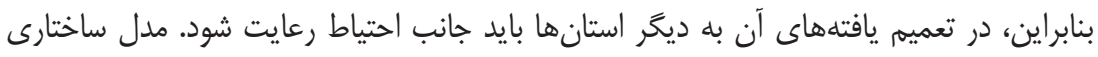

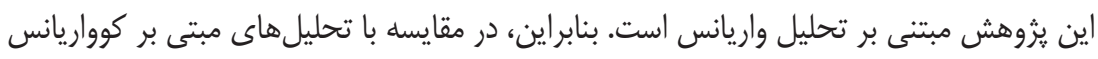
از توان آمارى يايينترى برخوردار است.

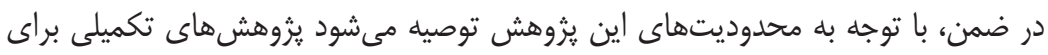

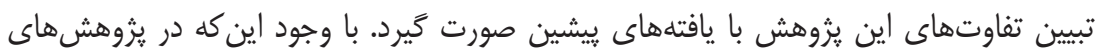

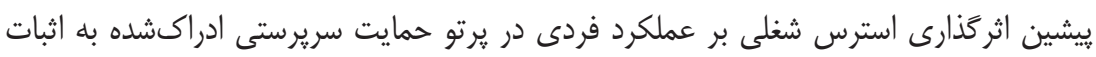

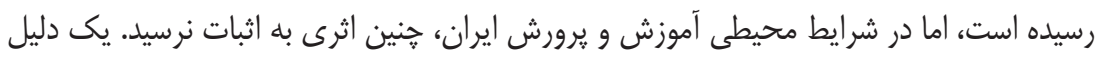

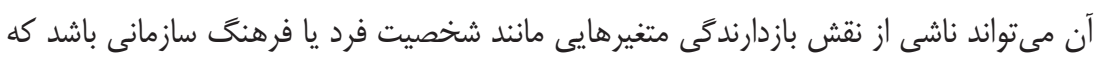

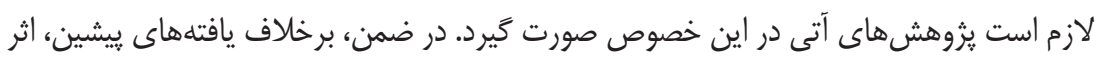

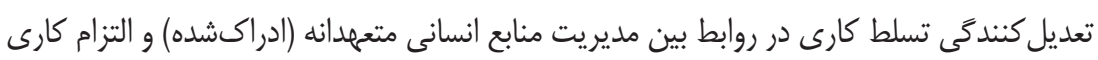

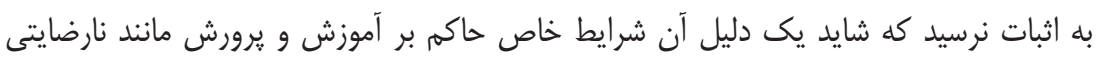

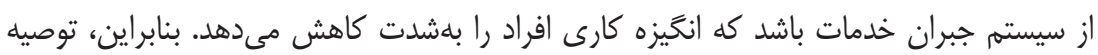

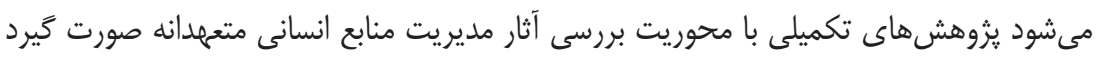

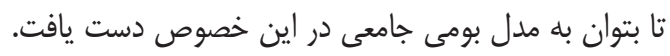




\section{منابع}

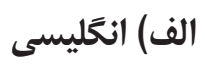

Boon, C., \& Kalshoven, K. (2014). How High-Commitment HRM Relates to Engagement and Commitment: The Moderating Role of Task Proficiency. Human Resource Management, 53(3), 403-420.

Borman, W. C., \& Motowidlo, S. (1993). Expanding the Criterion Domain to Include Elements of Contextual Performance. In N. Schmitt \& W. C. Borman (Eds.), Personnel Selection in Organizations. Psychology Faculty Publications.

Brough, P., \& Frame, R. (2004). Predicting Police Job Satisfaction and Turnover Intentions: The Role of Social Support and Police Organizational Variables. New Zealand Journal of Psychology, 33(1), 8-18.

Buuri, D. W. (2015). Performance Measurement Practices and Employee Productivity in the Insurance Firms in Kenya. (Degree of Master of Business and Administration), University of Nairobi.

Campbell, J. P. (1990). Modeling the Performance Prediction Problem in Industrial and Organizational Psychology. In M. D. Dunnette \& L. M. Hough (Eds.), Handbook of Industrial and Organizational Psychology (p. 687-732). Consulting Psychologists Press.

Dajani, M. A. Z. (2015). The Impact of Employee Engagement on Job Performance and Organizational Commitment in the Egyptian Banking Sector. Journal of Business and Management Sciences, 3(5), 138-147.

Dalal, R. S. (2005). A Meta-Analysis of the Relationship between Organizational Citizenship Behavior and Counterproductive Work Behavior. Journal of Applied Psychology, 90(6), 1241-1255.

Datta, D. K., Guthrie, J. P., \& Wright, P. M. (2005). Human Resource Management and Labor Productivity: Does Industry Matter? Academy of Management Journal, 48(1), 135-145.

Eisenberger, R., Stinglhamber, F., Vandenberghe, C., Sucharski, I. L., \& Rhoades, L. (2002). Perceived Supervisor Support: Contributions to Perceived Organizational Support and Employee Retention. Journal of Applied Psychology, 87(3), 565-573.

Etzion, D. (1984). Moderating Effect of Social Support on the Stress-Burnout Relationship. Journal of Applied Psychology, 69(4), 615-622.

Fu, W., \& Deshpande, S. P. (2014). The Impact of Caring Climate, Job 
Satisfaction, and Organizational Commitment on Job Performance of Employees in a China's Insurance Company. Journal of Business Ethics, 124(2), 339-349.

Haines III, V. Y., \& St-Onge, S. (2012). Performance Management Effectiveness: Practices or Context? The International Journal of Human Resource Management, 23(6), 1158-1175.

Hitt, M., Miller, C., \& Chet, C. (2006). Organizational Behavior: A Strategic Approach. USA: John Wiley\& Sons.

Jiang, K., Lepak, D. P., Hu, J., \& Baer, J. C. (2012). How Does Human Resource Management Influence Organizational Outcomes? A MetaAnalytic Investigation of Mediating Mechanisms. Academy of Management Journal, 55(6), 1264-1294.

Kang, S.-W., \& Kang, S.-D. (2016). High-Commitment Human Resource Management and Job Stress: Supervisor Support as a Moderator. Social Behavior and Personality: An International Journal, 44(10), 1719-1731.

Keller, R. T. (1984). The Role of Performance and Absenteeism in the Prediction of Turnover. Academy of Management Journal, 27(1), 176-183.

Koopmans, L., Bernaards, C. M., Hildebrandt, V. H., de Vet, H. C., \& van der Beek, A. J. (2014). Measuring Individual Work Performance: Identifying and Selecting Indicators. Work, 48(2), 229-238.

Kotteeswari, M., \& Sharief, S. T. (2014). Job Stress and Its Impact on Employees Performance a Study with Reference to Employees Working in Bpos. International Journal of Business and Administration Research Review, 2(4), $18-25$.

Lepak, D. P., Liao, H., Chung, Y., \& Harden, E. E. (2006). A Conceptual Review of Human Resource Management Systems in Strategic Human Resource Management Research. Research in Personnel and Human Resources Management, 25(1), 217-271.

Lussier, R. N., \& Hendon, J. R. (2017). Human Resource Management: Functions, Applications, and Skill Development: Sage Publications.

Monnot, M. J., \& Beehr, T. A. (2014). Subjective Well-Being At Work: Disentangling Source Effects of Stress and Support on Enthusiasm, Contentment, and Meaningfulness. Journal of Vocational Behavior, 85(2), 204-218.

Nishii, L. H., Lepak, D. P., \& Schneider, B. (2008). Employee Attributions of the "Why" of HR Practices: Their Effects on Employee Attitudes and Behaviors, and Customer Satisfaction. Personnel Psychology, 61(3), 503-545.

Park, O., Bae, J., \& Hong, W. (2019). High-Commitment HRM System, HR Capability, and Ambidextrous Technological Innovation. The International 
Journal of Human Resource Management, 30(9), 1526-1548.

Pfeffer, J. (1998). The Human Equation Boston: MA: Harvard Business School Press.

Prieto, I. M., \& Pilar Pérez Santana, M. (2012). Building Ambidexterity: The Role of Human Resource Practices in the Performance of Firms from Spain. Human Resource Management, 51(2), 189-211.

Purcell, J., \& Hutchinson, S. (2007). Front-Line Managers as Agents in the HRM-Performance Causal Chain: Theory, Analysis and Evidence. Human Resource Management Journal, 17(1), 3-20.

Renz, D. O. (2016). The Jossey-Bass Handbook of Nonprofit Leadership and Management: John Wiley \& Sons.

Rotundo, M., \& Sackett, P. R. (2002). The Relative Importance of Task, Citizenship, and Counterproductive Performance to Global Ratings of Job Performance: A Policy-Capturing Approach. Journal of Applied Psychology, 87(1), 66-80.

Schaufeli, W., Taris, T., Le Blanc, P., Peeters, M., Bakker, A., \& De Jonge, J. (2001). Maakt arbeid gezond. Op zoek naar de bevlogen werknemer [Does work Make Happy, 36(1), 422-428.

Sun, L.-Y., Aryee, S., \& Law, K. S. (2007). High-Performance Human Resource Practices, Citizenship Behavior, and Organizational Performance: A Relational Perspective. Academy of Management Journal, 50(3), 558-577.

Topcic, M., Baum, M., \& Kabst, R. (2016). Are High-Performance Work Practices Related to Individually Perceived Stress? A Job DemandsResources Perspective. The International Journal of Human Resource Management, 27(1), 45-66.

Van Dyne, L., \& LePine, J. A. (1998). Helping and Voice Extra-Role Behaviors: Evidence of Construct and Predictive Validity. Academy of Management Journal, 41(1), 108-119.

Viswesvaran, C., \& Ones, D. S. (2000). Perspectives on Models of Job Performance. International Journal of Selection and Assessment, 8(4), 216-226.

Viswesvaran, C., Sanchez, J. I., \& Fisher, J. (1999). The Role of Social Support in the Process of Work Stress: A Meta-Analysis. Journal of Vocational Behavior, 54(2), 314-334.

Wetzels, M., Odekerken-Schröder, G., \& Van Oppen, C. (2009). Using PLS Path Modeling for Assessing Hierarchical Construct Models: Guidelines and Empirical Illustration. MIS Quarterly, 33(1), 177-195.

World Health Organization. (1948). World Health Organization Constitution. Geneva, Switzerland. 